\title{
Rules and Limitations as a Pedagogical Problem of the Children Behavior Development in the Family and School
}

\author{
Pero Spasojević, Dragica Milinković, Sanja Opsenica, Milenko Ćurčić \\ Faculty of Education Bijeljina, University of East Sarajevo, Bijeljina, Bosnia and Herzegovina \\ Email: spero@teol.net, sadra@teol.net, sanjalopsenica@gmail.com, ljekobilje@teol.net
}

How to cite this paper: Spasojevic, P., Milinković, D., Opsenica, S. and Curčić, M. (2018) Rules and Limitations as a Pedagogical Problem of the Children Behavior Development in the Family and School. Open Journal of Social Sciences, 6, 256-268. https://doi.org/10.4236/jss.2018.65019

Received: April 14, 2018

Accepted: May 26, 2018

Published: May 29, 2018

Copyright (c) 2018 by authors and Scientific Research Publishing Inc. This work is licensed under the Creative Commons Attribution International License (CC BY 4.0).

http://creativecommons.org/licenses/by/4.0/

\begin{abstract}
Parents and educators often ignore the most favorable way of influencing the behavior of children by jointly building restrictions in all spheres of life, with the intention that they should be voluntarily accepted by children, public and adults. On the other hand, outdated forms of "forcing a child" are still not abandoned in behavior and learning in which the child is only an adult's workplace. Disclaimer of active action on the behavior of the child in the family and the active establishment of rules on cooperative relations between children and adults in kindergarten, parents and educators, the development of each child individually expose the risk and enable the process to be launched in various ways. The aim of the empirical part of the work is the practice of forming the desirable behavior of children in the family and school and the consequences that arise if the development of behavior is left to the environmental effects of the environment and patterns in which families and schools are not involved at all. Using descriptive method and the technique of interviewing on a random sample of 145 parents of children before going to school, results have led to results that suggest the use of a personal example in education, which is implicitly established as a rule, and on the parents' involvement and the influence of the environment as factors contributing to the "bad" behavior of children.
\end{abstract}

\section{Keywords}

Behavior, Children, Development, Rules and Limitations, Parents and Educators

\section{Introduction}

The paper presents support to family, kindergartens and elementary schools in 
one of the most prominent functional problems of methodology of family and school work in order to systematically influence the development of behavior and to prevent the abundance of particularly school excesses in the field of behavior development and functional problems of organizing and managing school processes. On the other hand, the context of the work is also general results of education in the light of numerous complaints, as the school itself educates itself, and does not educate, no matter how much they can be justified or unfounded, no matter how much they "flee from reality and responsibility" towards conformism. It is completely clear that there is no way that schools in the near future change the pedagogical climate in relations among its subjects, if they do not actively engage, together with their family, in the pedagogical activities of the most effective way of natural action to develop behavior. It is indisputable that more is concerned with the social participation of students and their parents and some elements of authentic democracy in schoolwork, the freedom of expression and the creation of all students, including children with any kind of developmental disability. According to Pero Spasojević et al. (2017) [1], earlier studies have warned that emotional problems, and behavioral, in this regard, appear at a very early age, so it is logical for institutions to have good assessments of the behavior and habits of children at the time of schooling and, in this regard, quality programs acting on the development of behavior, in order to be able to "liberate" the development potential of each individual in a timely manner, through pedagogically acceptable and qualitative interventions.

However, the "internal division" of the school, according to Pero Spasojević (2011) [2], instead of the integrity and diverse social interaction of children "outside the department", contributes to the fact that children rarely adequately learn social roles, especially "responsibility" for what happens in school, and not just in their classroom will significantly affect their behavior. This internal division into ages, to "good and evil" is the unsustainable and possibly the most harmful practice that favors the creation of "school clans" and peer violence. Each department in the school is a "world for itself", a small community that does not allow the influence of others, and even those with the experiences they carry within themselves, precious for subtle interaction and the formation of the personality of each student. The standards governing the size of school groups and the size of schools are the most unfavorable in mega-schools, inherited from the era of real-socialism, where many planning and organizational functions are reduced to "imitating enterprises" in industry, although it is quite clear that schools are very Different, if not because of what, because of the nature of the non-pheral relationships of children of different ages, unlike the mutual relations of the elderly. The problem for oneself is a much more serious respect for the school in its midst and in general the functioning of the environment as a factor of development. However, since we know that there are great differences between "schools" and "schools", according to Antonio Herera and Petar Mandic (1989) [3], the only remaining answer for a successful and quality upbringing 
is the family which, in all likelihood, is what determines a move to the future, success or failure in further education and the overall development of a child.

According to Emil Kamenov and Pero Spasojević (2008) [4], this is, to a greater extent, the use of personal example in education, requirements that implicitly establish rules that the child will voluntarily adopt, at the beginning repeatedly, with the encouragement of adults, to become part of the child's conscious and willing action. Unfortunately, we are witnessing practices in which, in particular, parents are indifferent towards behavior development, believing in the thesis that it will form "in itself", which is completely unsustainable. It is mostly intuitive and non-systematic about behaviors that they can "perceive" as unacceptable, as potentially dangerous to the child, or what may be the subject of frequent condemnation in the immediate environment. According to Pero Spasojević (2011) [2], it is quite certain that parents can also bring some unfair convictions of the child, resorting to the "choking of freedom", forcing them to obscure and confusing patterns of behavior that, according to parents or the environment, are good, although it is evidently undeniable neglect of the obligations and responsibilities for children being adequately trained in what is expected of them.

\section{Developing the Behavior of Children in the Family and School}

There are few papers on the development of behavior in the literature. Compared to works devoted to the psychopathology of school children and youth, the impression is that, from the perspective of pedagogy, the development of behavior is extremely irrelevant, except for children with mental disorders in childhood. The narrower field of behavioral disorder studies is mainly in the function of prognosis for the needs of anticipation of action on the development and support of children with developmental disorders (bearing in mind also the so-called "behavioral disorders"). According to Emil Kamenov and Pero Spasojević (2008) [4], some authors explain this state of the difficulties in identifying behavioral disorders in childhood, especially the differentiation of typical and atypical forms of behavior at this age which is an evident pedagogical and psychological challenge in the diagnostic and methodological sense. Unlike the usual forms of psychopathology of childhood development, behavioral disorders are most often expressed as behavioral manifestations that are also evident in typically developed children, with children with behavioral disorders being much more frequent, more intense, and more durable. Alice S. Carter, Margaret J. Briggs-Gowan and Naomi Ornstein Davis (2004) [5] describe them as symptoms that correspond to descriptions of unadapted behavior during childhood, which are developmentally acceptable and transient. In other words, there are numerous examples in practice that behaviors that are considered at an older age to be relevant in assessing disturbances in development are taken at an early age as a manifestation of normal development. Thus, the age of the child and the 
central influences become key to "learning behaviors", regardless of the conformity of parents and the expectation that children adopt patterns of behavior expected by the center as "home care", praised in patriarchal conditions, emphasized most often in the positive sense of the word, as an example of obedience, diligence, devotion to family values. A typical example of learning is still in the earliest childhood, the onset of rage attacks during the second year, which can be explained by the need of a child to develop an image of self, consciousness, freedom and autonomy of action. Some theorists are of the opinion that the absence of rage attacks in this period can be the cause of later non-adapted behavior and cause interference in behavior. It is evident that there are no safe and clear boundaries between normal and psychopathological manifestations in behavior because they are blurred by rapid and intense developmental changes that occur during childhood. According to Lauren S. Waksclag et al. (2005) [6], the occurrence of unacceptable behavior directly depends on the flow and outcome of the processes that are common at this age, such as the development of self-control, learning and consolidating the skills of tolerance to frustration that children are often exposed to, the delay in meeting needs, the use of verbal strategies, internalisation of standards and behavioral flexibility. In this regard, behavioral disorders in childhood can be a completely real cause of developmentally, normatively unacceptable behavior at preschool age, such as disobedience and aggression, completely misunderstood and labeled as pathological. The aggravating circumstance is also that the criteria for setting diagnosis, which are given in contemporary universally accepted categorical classification systems, are not suitable for the younger age. The frequent occurrence of defiance and resistance to the routine of family life or institutions such as kindergarten and school are not a disorder in itself, but rather involves the manifestation of patterns of negativistic and defiant behavior according to authority figures. Behavioral disorders can be spoken when repeated, in the form of persistent patterns, behavior that violates the fundamental rights of others and conflicts with the appropriate norms and rules of individual possibilities of a child of a specific age (aggression against humans and animals, destruction of property, misappropriation or theft, and serious violation of the rule). According to Lauren S. Waksclag et al. (2005) [6], some of these symptoms, when it comes to children before going to school, at a time of "anxiety before going to school", are developmentally impossible or unlikely (e.g. "escaping from school”), while other symptoms occur within others normatively unacceptable behavior.

However, the school often encounters these forms of behavior, and, without a family, there is no chance that this pedagogical challenge will be resolved in the best possible way.

\section{The Influence of Parents on Behavior Development}

The basic idea is that behavior "must be learned", acquired in "life context", by establishing psychological mechanisms of autonomy and self-control, in the ear- 
liest childhood, which rarely appears in the family. Outside the "space of intuitive pedagogy", little is believed in the child's authentic freedom, although the growth and development of the child inevitably becomes increasingly independent of the family. Contrary to this idea, both in the family and in school, "coercion" is applied to acceptable behavior, which necessarily involves certain sanctions, if a certain "housekeeping" is violated, or an unwritten code of conduct in relations between children and the elderly, or the children "are left alone". According to William Glasser and Carleen Glasser (2007) [7], within the family, the most important assumption is a quality "marriage relationship, by itself" as a source of happiness and understanding, without which there is no healthy family or a successful child upbringing.

According to the survey of parents in this study, the empirical data on behavior development indicate the connection and the impact of independent variables: half the child, age, number of children in the family, birth order, family members living with parents and children, development of behavior and choice of parental procedures in the light of these socio-demographic characteristics of the family. According to Pero Spasojević et al. (2017) [1], to test and demonstrate connectivity, $\chi^{2}$ test was used, crossing independent variables and methods used by parents. For some variables, some categories are merged as an integral dependent variable in order to test statistical significance. Statistically significant results that follow in the text below will be tabulated.

The central concept of research is the construction of rules of behavior in the educational process, which, by its very nature, is not the exclusive right of the institution from which the family excludes. On the contrary, there is no successful upbringing in institutions without family, because they are natural allies and the optimum expectation for successful education and education, "healthy growth", are in their constant unity and exchange. Otherwise, both are exposed to numerous risks that go unnoticed and, thus, bring many difficulties in developing children with whom they cannot make their own choices. According to Pero Spasojević (2003) [8], today, there is a strong emphasis on the need to "prepare children for school", although, based on the basic meaning of school existence, a far more justified theory would be "to adapt school and prepare for the child", and that the environment is one of the crucial factors in the effects of upbringing, but also school achievements, it is understood, within the framework of quality partnerships with the family.

Respondents-parents during this study indicate that most of them understand the need to form clear rules (based on the principle of agreement and volunteering) and their consistent implementation. In addition, parents are aware of the importance of having rules in the educational process and do not call into question their application. However, the other results unambiguously show that the problem of consistency in attitudes in the "life context" is more pronounced, as many parents ignore the problem of persistence in implementing the rules. According to Sanja Opsenica (2012) [9], all this indicates that parents are in a 
split between what they should and how they are. The rules exist, but they are obviously selectively applied, resulting in the most dominant and inconsistent parenting style in education, with spoiled children who "educate their parents" instead of them. This only points to the marked need to introduce institutional support and help a wider social environment in teaching parents about upbringing. For successful parenting, besides the model of experience, which is most often chosen and mimicked by young parents, direct advisory support is needed, a systematic impact on the competencies of parents to influence the development of children in the most sensitive developmental age. The "School of Parenthood", for the sake of far-reaching benefits for social development, could and should be a priority problem of social development. Otherwise, the question of education is questioned as the basis of every social development and prosperity. In fact, it is hypocritical that one activity is "recognized" as a duty of special social interest, and at the same time, to observe the disastrous effects of the environment as a factor of action on development.

\section{Research Results and Discussion}

Our experiences are very skyscraper in relation to this activity of the society, since families are most often left to themselves or, at best, they are the subject of the work of the public welfare service, which individuals turn to only in the event of disrupted family relationships, or are insufficiently materialized. The problem of parents' help to achieve responsible parenting is multifaceted, because what is missed during its development in early childhood later becomes a much more difficult and "expensive" problem. Therefore, parents' counseling on procedures during adolescence is developmentally more resourceful and should be looked at in a well thought out and far more efficient way as an urgent problem of institutions.

The real pedagogical problem of parents is the construction of rules during adolescence, according to the observed developmental opportunities of the child, and they volunteer and volunteer in them, not to be forced to learn "normatively acceptable", but far from their experience and the possibilities of understanding "commonly built rules", which is intended to influence the development of behavior. From Table 1 is evident that 132 children (f), or 91\% of children, together with their parents, agree on "rules of conduct" and respect them consistently.

The question "Does your child avoid the rules set?" (Table 2) shows the natural need of the child to resist and fight for his freedom. According to Petar

Table 1. Do you jointly (agree) "rules of conduct" and that you are consistent in their respect?

\begin{tabular}{cccc}
\hline & Yes & No & $\Sigma$ \\
\hline $\mathrm{f}$ & 132 & 13 & 145 \\
$\%$ & 91.0 & 9.0 & 100.0 \\
\hline
\end{tabular}


Stojaković (2012) [10], Sam Erikson in his Theory of Psychosocial Development emphasized the necessity of children's need to explore, question, initiate activity in the third stage of personality development, in the so-called period of the game, which is the backbone of creating ambitions in the later period of life. All this tells about the difficulty and challenges parents face in building a child's personality. Although the vast majority claim to build behavioral codes together with children, there are contradictions in subsequent responses that lead them to the need to provide socially acceptable answers instead of objective action.

One of the most important development tasks in childhood is the formation of habits related to "healthy life", habits of eating, hygiene, sleeping, because these habits are later transferred to the formation of habits in the school. The obtained results indicate that a higher proportion of children do not have clearly adopted rules relating to going to bed, but parents are "lenient" regardless of persistent consequences (Table 3).

It is a disturbing fact that a large percentage of children do not have any family responsibilities and obligations on their own (Table 4). It is a belief that small children need to "protect" from some duties, even though they would be happy to participate in them. Children are in fact denied valuable developmentally useful experiences with "the best" intention of parents to protect them, in this extremely harmful way.

The question: "Does your child have an idol?" (Table 5), which relates to the

Table 2. Does your child avoid rules?

\begin{tabular}{cccc}
\hline & Yes & No & $\Sigma$ \\
\hline $\mathrm{f}$ & 56 & 38.6 & 145 \\
$\%$ & 89 & 61.4 & 100.0 \\
\hline
\end{tabular}

Table 3. Does your child go to bed at night for a certain amount of time?

\begin{tabular}{cccc}
\hline & Yes & No & $\Sigma$ \\
\hline $\mathrm{f}$ & 77 & 68 & 145 \\
$\%$ & 53.1 & 46.9 & 100.0 \\
\hline
\end{tabular}

Table 4. Does your child have some responsibilities in a family that performs independently and for whom it assumes responsibility?

\begin{tabular}{cccc}
\hline & Yes & No & $\Sigma$ \\
\hline $\mathrm{f}$ & 79 & 66 & 145 \\
$\%$ & 54.5 & 45.5 & 100.0 \\
\hline
\end{tabular}

Table 5. Does your child have an idol?

\begin{tabular}{|c|c|c|c|c|c|}
\hline & \multicolumn{3}{|c|}{ Yes } & \multirow{2}{*}{ No } & \multirow{2}{*}{$\Sigma$} \\
\hline & Dady & Cartoon characters & Singers & & \\
\hline $\mathrm{f}$ & 6 & 15 & 4 & 4 & 29 \\
\hline$\%$ & 20.69 & 51.72 & 13.79 & 13.79 & 100.00 \\
\hline
\end{tabular}


impact on the child's personality and the objective effects of this influence, shows how much the impact of the imaginary world, the cartoon world, is evident in $51.7 \%$ of cases. However, it is obvious that cartoon characters are often not similar to identifying characters, because they most often offer an erroneous behavioral pattern, which is, in fact, a cultural reflection and a reflection of the social values present in the environment in which we live.

Interesting is the data obtained by the study which says that a large number of respondents (73\%) of parents "do not calm" the child with the help of modern electronic devices, and in reality, there is a more and more present picture of a child who hypnotized the key on the phone display, according to Vlasta Ilišin, Ankica Marinović Bobinac and Furio Radin (2001) [11]. Is it denying and denying a parenting mechanism that is aware of the bad influence of the phone and the need to present it in a socially desirable light!? Whatever it is, it is obviously necessary to warn parents and raise awareness about the harmful effect of electronic devices on the development of a child's personality.

According to Pero Spasojević et al. (2017) [1], in other words, regardless of the awareness of the harmful effects of electronic devices and content provided by these devices, the absence of any parental control creates preconditions for long-term detrimental effects and the renunciation of parental responsibility for the effects of early childhood education.

Sex has been shown to be statistically significantly related to the procedures used by parents (e.g., calming the child) because parents "approve" the use of phones, tablets (computers) and the like to calm the child $\left(\chi^{2}=5.49\right.$; $\left.<0.05\right)$. It is interesting that parents use this more often for boys (35.6\%) than for girls (18.1\%) (Table 6).

This phenomenon is probably in the patriarchal family's heritage, in which male children were treated differently, which, as such, today reflects on gender equality. In most families, this is not based on rational reasons, since parents do not make any difference in their explanations, but in actions they unconsciously attack the male sex.

Alfred Adler (1956) [12] is the first theoretician to point out the significance of the number of children in the family to form a child's personality, and the results of the research confirm (Table 7).

The results indicate that there is a significant correlation between the number of children in the family and the independence of the child when bathing is

Table 6. Do you calm your child by giving a phone, tablet (computer), etc.?

\begin{tabular}{ccccccc}
\hline & \multicolumn{2}{c}{ Yes } & \multicolumn{2}{c}{ No } & \multicolumn{2}{c}{$\Sigma$} \\
\hline & $\mathrm{f}$ & $\%$ & $\mathrm{f}$ & $\%$ & $\mathrm{f}$ & $\%$ \\
\hline Male & 26 & $35.6 \%$ & 47 & $64.4 \%$ & 73 & $100.0 \%$ \\
Ladies & 13 & $18.1 \%$ & 59 & $81.9 \%$ & 72 & $100.0 \%$ \\
In total & 39 & $26.9 \%$ & 106 & $73.1 \%$ & 145 & $100.0 \%$
\end{tabular}

$\chi^{2}=5.49 ;<0.05$ 
Table 7. Does your child buy it yourself?

\begin{tabular}{ccccc}
\hline \multicolumn{2}{c}{ Number of children in the family } & Yes & No & In total \\
\hline \multirow{2}{*}{ One } & $\mathrm{f}$ & 2 & 23 & 25 \\
& $\%$ & $8.0 \%$ & $92.0 \%$ & $100.0 \%$ \\
Two or more & $\mathrm{f}$ & 43 & 77 & 120 \\
& $\%$ & $35.8 \%$ & $64.2 \%$ & $100.0 \%$ \\
In total & $\mathrm{f}$ & 45 & 100 & 145 \\
& $\%$ & $31.0 \%$ & $69.0 \%$ & $100.0 \%$ \\
\hline
\end{tabular}

$\chi^{2}=7.489 ; \mathrm{p}<0.01$

concerned $\left(\chi^{2}=7.489 ; \mathrm{p}<0.01\right)$. In families with several children, independence and independence are developing, as children, by modeling, adopt behavior patterns of older brothers and sisters, while in families with one child parents are most often pedocentric and make irreparable mistakes that affect the construction of the wrong lifestyle in children.

In support of this, the fact is that there is a significant correlation between the number of children in the family and the number of hours a day spent watching a television using a computer tablet $\left(\chi^{2}=14.946 ; \mathrm{p}<0.01\right)$. A large number of children's units watched television, used computers and tablets 3 hours (52\%), compared to children in whose family there were more children $(22 \%)$. This shows that families with one child cannot build clear and rigid rules that will be consistently applied. This is a child's pre-emptive and significant privileges that later adversely affect the overall development and autonomy. The result is numerous difficulties in social communication with the environment, including a greater number of conflicts, insecurity and significantly reduced responsibility for their own work. It mostly affects school success, because the child is in the development of personality, encouraged that his responsibilities are taken over by others, that he experiences himself and demands conditions similar to those during his growing up.

It has also been shown that the order of birth of the child is significantly related to behavior $\left(\chi^{2}=12.184 ; \mathrm{p}<0.01\right)$. If the child was first born, the probability was that the parent attributes his bad behavior to his own actions (51\%), but if the child is second, third or fourth in order of birth (26\%). The assumption is that young parents have increased awareness and much stronger attitudes in the educational approach towards the first child. The need to give the maximum in educating the child is dominant because they are very dedicated to their role because they are aware of their responsibility and are constantly being questioned and blamed for educational mistakes. Adequate criteria are delayed by time, so that the "next" children are "dropped out" and if the child is second, third or fourth in order of birth, the higher the probability is that the parent does not know the reason for the bad behavior of the child (27\%), but if the child is first born (12\%). 
A very important factor for building rules and constraints is the number of household members. There is a significant correlation between the data on whether there is another person other than parents and children in the family, and whether the child goes to sleep at any given time $\left(\chi^{2}=6.211 ; \mathrm{p}<0.05\right)$ (Table 8). More children went to sleep for a specific time if they live with their parents only (62\%), but if another family (grandparents, aunt, uncle) lives in the family (41\%), which means that many people are influenced that the rules are not perceived as absolute and that they are more flexible if a lot of people take part in the upbringing of the child.

Since the paper deals with the achievement of parenthood in early childhood, it is necessary to point out the concrete and sufficiently explored directions of family education and training of parents for partnership with institutions as the only way out for joint action and effective support for the development of children:

- The necessity of "active learning" and preparation for parental functions, helping parents discover their own parental abilities and thus reducing their own sense of dependence on others, encouraging them to take maximum responsibility for their own learning and to see themselves as persons who can act and can change themselves, to influence the development and behavior of their children, which is of great importance for kindergartens and schools.

- Every parent's learning is best suited to direct activities-learning by their own experience in solving a problem when involving a child in a kindergarten or school, rather than just listening to problems.

- Parents' awareness of the goals and expected outcomes-which parents will know more about the potential for influencing the development of the child, will pay more attention to their own actions and try to avoid mistakes and inadequate behavior.

- When working with parents, institutions always rely on what parents already know and apply-it requires good mutual knowledge, so that mutual support is a pleasure, and not yet "one more obligation".

- In an attempt to realistically start the ideas started with this work, the "School for Parents" Program was created on a small sample of schools, with

Table 8. Relationship between the number of household members and the departure of a child to sleep.

\begin{tabular}{lrrrrc}
\hline \multicolumn{2}{c}{ Does your child go to sleep at any given time every night? } & Yes & No & In total \\
\hline & Yes & $\mathrm{f}$ & 25 & 36 & 61 \\
& & $\%$ & $41.0 \%$ & $59.0 \%$ & $100.0 \%$ \\
$\begin{array}{c}\text { In addition to parents and children in the } \\
\text { family, another person lives. }\end{array}$ & No & $\mathrm{f}$ & 52 & 32 & 84 \\
& & $\%$ & $61.9 \%$ & $38.1 \%$ & $100.0 \%$ \\
& In total & $\mathrm{f}$ & 77 & 68 & 145 \\
& & $\%$ & $53.1 \%$ & $46.9 \%$ & $100.0 \%$ \\
\hline
\end{tabular}

$\chi^{2}=6.211 ; \mathrm{p}<0.05$ 
the help of professional associates and teachers. During this attempt, it is particularly interesting to think of a respectable number of respondents $(41.4 \%)$ that "the role of the family at school" is not the same as it always was, which is encouraging and suggests that there is a mood that parents more helpful and more concrete help the functioning of the school, although is still a dominant group of traditional relationships.

- The family has its duties and responsibilities in relation to the child, and their schools-one for the others can do much more, the attitude is supported by the majority of polled respondents $(62.7 \%)$, which is one of the encouraging results, since it can be optimistic to look at potential programs for involving parents in school work.

- Discouraging the attitude of the respondents about the thesis that families and schools need to better cooperate with the goal of helping the child develop behavior. $72 \%$ of the respondents question this in which the tendency of a strict division of competences is recognized, and not a partnership. Since it is a "behavior", it is likely that this notion has caused some confusion, due to which the respondents did not express their readiness to share the responsibility for the effects of joint development on development.

- The opinion of most respondents (72\%) is also surprising, which negates the need for families and schools to better cooperate with the goal of helping the child learn and achieve better schooling. It's probably a bad experience from traditional school practice. Respondents also showed suspicion (72\%) of the view that family and school can provide to each other a lot of information about the child's progress and possible difficulties, which is probably a consequence of the current school practice in which parents appear in school only because of "some kind of occasion", "Urgent" school needs.

- The thesis that schools should train parents for a more successful function of upbringing children, opinions are divided, even though there are a large number of those who deny this absolutely necessary necessity (50.7\%). It is agreed with $34.6 \%$, while undecided (or indifferent) $14.7 \%$. Although, at first glance, this source of deepening the school crisis is probably a long-standing institutional crisis, although in this time, it is most important to preserve school as a healthy support of society. This cannot be achieved by its constant challenge but by socially appropriate support.

\section{Conclusions}

Although this work is merely an attempt to illuminate one of the most serious problems of today, expressed through a comprehensive "school crisis", the parents' unwillingness to face the most responsible function of the family, the educational function, there are far more complex and significant problems that may cause serious damages in upbringing and education, most often "with the best intentions" of the parents. The question arises as to whether they do so consciously and deliberately, or are they left to manage how they know and howl?! 
Does a civilised society in which education is regulated as a "system" unconsciously neglect "family upbringing" as part of that system and why do we have low expectations from the family, although scientific truths are completely on the other side?!? Apparently, in a system for which we are not sure if it functions at all, because it is not vertically interconnected and has no continuity, everyone works for itself, the family, as the first environment for early learning, most contributes to that system in its own way. What would happen if the family was significantly strengthened, trained, better educated on the essence of developmental problems of children in early childhood? These are all issues that pedagogy rarely deals with, although there are many serious reasons for this.

On the other hand, the sociological phenomena of the New Age family, such as the high percentage of divorces of young marriages, carry in themselves the inherent dangers of relationships in which the family cannot be an adequate learning environment. If the reasons for getting married are more complex, we will find that marriages are often initiated by unwanted pregnancy. This means that young absolutely unprepared go into adventures in which they seem to be realized as adults, and in reality, as adventurers, neglecting the consequences that always have an uncertain outcome. Unfortunately, the consequences of mistakes are indelible, because immature parents create immature offspring, children become the biggest sufferers, so the question arises as to whether some mistakes can be avoided or remedied at all. Cultural framework in which families appear and the distorted system of values clearly indicate to the uncertain future of the society and the absence of responsible parenthood, especially regarding the performance of educational values.

What poses as a potential solution is to raise awareness among institutions that deal with family, to strengthen social initiative in training young people about marriage and family, about the inevitability of its foundation for self-actualization, because human potentials are probably not possible anywhere in parenting.

In this regard, there is a need for young people to get involved in the active editing of social life already during the high school age, to have the support of an advisory rather than a normative nature, to learn, in the life context, of the monsters of the new age and the dangers that lie down.

In the end, the unique conclusion of this discussion could be that learning behavior by the existence and building of rules is a good pedagogical process and that "strengthening" of parents can bring many benefits to the school, can innovate practice and improve a range of educational functions of the school.

\section{References}

[1] Spasojević, P., Opsenica, S., Travar, M., Miljenović, S., Mojić, D. and Rakić, C. (2017) Škola roditeljstva, za učitelje i roditelje djece mlađeg školskog uzrasta. [School of Parenting, for Teachers and Parents of Children of the Younger School Age.] Bijeljina: Univerzitet u Istočnom Sarajevu, Pedagoški fakultet Bijeljina, Banja Luka: Republički pedagoški zavod Republike Srpske. 
[2] Спасојевић, П. (2011) Породична педагогија и одговорно родитељство. [Family Pedagogy and Responsible Parenting.] ИП, Нова школа плус. Бијељина: Универзитет у Источном Сарајеву, Педагошки факултет, Лакташи.

[3] Herera, A. and Mandić, P. (1989) Obrazovanje za XXI stoljeće. [Education for the XXI Century.] Sarajevo: Svjetlost, Beograd: Zavod za udžbenike i nastavna sredstva.

[4] Kamenov, E. and Spasojević, P. (2008) Predškolska pedagogija. [Preschool Pedagogy.] Pedagoški fakultet, Bijeljina.

[5] Carter, A.S., Briggs-Gowan, M.J. and Davis, N.O. (2004) Assessment of Young Children's Social-Emotional Development and Psychopathology: Recent Advances and Recommendations for Practice. Journal of Child Psychology and Psychiatry, 45, 109-134. https://doi.org/10.1046/j.0021-9630.2003.00316.x

[6] Waksclag, L.S., Leventhal, B.L., Briggs-Gowan, M.J., Danis, B., Keenan, K., Hill, C., et al. (2005) Defining the "Disruptive" in Preschool Behavior: What Diagnostic Observation Can Teach Us. Clinical Child and Family Psychology Review, 8, 183-201. https://doi.org/10.1007/s10567-005-6664-5

[7] Glasser, V. and Glasser, C. (2007) Naći se i ostati zajedno, rješavanje zagonetke braka. [Find and Stay Together, Solve the Puzzle of MARRIAge.] Alinea, Zagreb.

[8] Spasojević, P. (2003) Igra i rano učenje-Programi ranog učenja usmjereni na dijete. [Play and Early Learning-Early Childhood Education Programs.] Zavod za udžbenike i nastavna sredstva, Srpsko Sarajevo.

[9] Опсеница, С. (2012) Васпитни стилови као детерминанте независности младих. [Educational Styles as Determinants of Youth Independence.] Нова школа, часопис за теорију и праксу савремене школе и предшколства, 9/10, 257-268.

[10] Stojaković, P. (2012) Prvih šest je najvažnije, psihologija za vaspitače i roditelje. [The First Six Are the Most Important, Psychology for Educators and Parents.] Grafid, Banja Luka.

[11] Ilišin, V., Marinović Bobinac, A. and Radin, F. (2001) Children and the Media (Djeca i mediji). Institut za društvena istraživanja, Državni zavod za zaštitu obitelji, materinstva i mladeži, Zagreb.

[12] Adler, A. (1956) The Individual Psychology of Alfred Adler. Ansbacher, H.L. and Ansbacher, R.R., Eds. Harper Torchbooks, New York. 